\title{
Zero Waste Pattern for Small and Medium Enterprises (SMEs) in Indonesia, Using the Concept of Blue Economy
}

\author{
Muhamad Mujahidin ${ }^{1}$, Bunga Paramita ${ }^{2}$ \\ \{mujahidin@umrah.ac.id ${ }^{1}, \underline{\text { bungaparamita1@umrah.ac.id }}{ }^{2}$ \} \\ ${ }^{1,2}$ Raja Ali Haji Maritime University
}

\begin{abstract}
ABCG (Academic, Business, Community, Government) is essential in economy development. The integrated industrial cultivation system is one of the implementations in the development of a Blue Economy that is able to development activities without waste, Waste water originating from domestic waste and clinical wastewater in general contain organic pollutant compounds which are quite high and can be processed by processing biologically, A prototype for a Zero waste pattern and industrialization in the economic field are currently two issues that contradict the world's environmental sustainability. The concept of sustainable development is one of the efforts to preserve the environment. Indonesia is one of the countries that supports the implementation of the concept of sustainable development, one of which is the Blue Economy concept. As a maritime country, Indonesia is biodiverse so the Blue Economy concept is seen as more efficient. The methods used are Refuse, Reduce, Reuse, Recycle and Rot, because they try to offer solutions to the challenges of the world economy by systems that tend to be exploitative for the management design of the Marine and fisheries sector. which currently can be admitted is still not optimal. This socialization uses the concept of the zero waste pattern theory of SMEs on the Blue Economy concept with descriptive and qualitative research methods. The implementation of the Blue Economy concept in community empowerment in coastal areas is carried out by revitalizing sustainable development. This is actualised by using the concept of aquaculture digitization to support food independence and security in the maritime sector through the development of competitive and innovative downstream fishery products. Constraints faced in this socialization are that sustainable concept changes depend on reference to the government's definition as an example of the category of micro, small and medium enterprises (SMEs). These are more labor intensive compared to large enterprises (UB) which are more capital intensive.
\end{abstract}

Keywords: Zero Waste, Blue Economy, SMEs, ABCG (Academic, Business, Community, Government)

\section{Introduction}

Environmental pollution is living things, substances and energy that exceed the established environmental quality standards., Pollution or environmental pollution is a change in the environmental order between humans and living things by natural processes, so that the quality of the environment cannot function. , Environmental pollution causes harm to living things,for example, carbon dioxide levels that exceed $0.033 \%$ can have a damaging effect; $\mathrm{Pb}$, $\mathrm{Hg}, \mathrm{Zn}$, and $\mathrm{CO}$, can accumulate and are toxic. Organic waste decomposed by bacteria causes 
oxygen in the water to decrease and interferes with aquatic life., Previous research on the landfill control method found that the methane gas produced in landfills is difficult to control and requires more storage media. The limitations of research on the sanitary landfill method is that the facilities and infrastructure that are applied are too expensive. As a result, it is difficult for small-scale UMKM actors to implement (Suryono dan Budiman,2010). The biological wastewater treatment process can be carried out under aerobic conditions(with air), anaerobic conditions (without air) or a combination of anaerobic and aerobic. Process Aerobic biologics are usually used for wastewater treatment with low BOD loads too large, while anaerobic biological processes are used for wastewater treatment with very high BOD load.

Biological wastewater treatment can be broadly divided into three, namely: biological process with suspended culture, biological process with culture attached culture and processing with a lagoon or pond system. Biological process with suspended culture is a treatment system using activity of micro-organisms to decompose pollutant compounds present in water and the microorganisms used are cultured in suspension in a reactor. Some examples processing processes with this system include: standard or conventional activated sludge processes (standard activated sludge), step aeration, contact stabilization, extended aeration, oxidation ditch(oxidation pool ditch system) and others. Biological process with embedded culture is a waste treatment process in which the microorganisms used are cultured on a medium so that the microorganisms adhere to the surface of the medium. This process is also known as the microbiological film process or biofilm process. Some examples of wastewater treatment technologies in this way include: trickling filter, immersed biofilter, rotary biological contactor (RBC), contact aeration/oxidation (contact aeration) and others.

The process of biological wastewater treatment with a lagoon or pond is by accommodate waste water in a large pond with a long residence time so that with the activity of micro-organisms that grow naturally, the existing pollutant compounds in water will decompose. To speed up the process of decomposition of pollutant compounds or shortening residence time can also be carried out the aeration process. One example process Waste water treatment in this way is an aeration pond or a stabilization pond ponds). Processes with the lagoon system are sometimes categorized as biological processes with suspended cultures. development of a comprehensive blue economy emphasizes innovation and processing of raw materials without leaving waste (Zulham,2012), The purpose of the research is to review the application of the concept of "Blue Economy" in, content analysis, descriptive and reviewed from the social and economic aspects explained qualitatively(Sumantri, 2005). technology or process that will be used for wastewater treatment, several things that need to be considered include: characteristics of wastewater, amount of waste and expected quality standards of treated water. Types of bacteria require a certain $\mathrm{pH}$ to grow properly. In general, all bacteria have growth conditions between $4-9.5$ with an optimum $\mathrm{pH}$ of $6.5-7.5$. Overall, Reynolds (1985) stated that microorganisms need a $\mathrm{pH}$ of 6.5-9. Bacteria will grow well in slightly alkaline conditions, ranging from 7-8 (Flathman, 1994).

\section{Theory}

Wastewater treatment technology has its own advantages and disadvantages, therefore in terms of selecting the type of technology it is necessary to pay attention to technical aspects, economic aspects and environmental aspects. Waste water in the form of solvents that are B3 (Hazardous and Toxic Materials) including chloroform, antiseptic, acid, etc., expired 
drugs/chemicals, etc., is carried out by burning at high temperatures with an incinerator or can be carried out by sending it to a B3 waste treatment site.wastewater treatment processes, especially those containing organic pollutant compounds, the technology used mostly uses micro-organism activities to decompose these organic pollutant compounds. The wastewater treatment process with the activity of micro-organisms is commonly referred to as "Biological Process". The biological wastewater treatment process can be carried out under aerobic conditions (with air), anaerobic conditions (without air) or a combination of anaerobic and aerobic. Aerobic biological processes are usually used to treat wastewater with a low BOD load, while anaerobic biological processes are used to treat wastewater with very high BOD loads.

Biological wastewater treatment can be broadly divided into three, namely biological processes with suspended culture, biological processes with attached culture and treatment processes using a lagoon or pond system. Biological process with suspended culture is a treatment system using the activity of micro-organisms to decompose pollutant compounds present in the water and the micro-organisms used are cultured in suspension in a reactor. Some examples of processing processes with this system include: standard activated sludge processes (standard activated sludge), step aeration, contact stabilization, extended aeration, oxidation ditch (ditch system oxidation pond).

\section{Method}

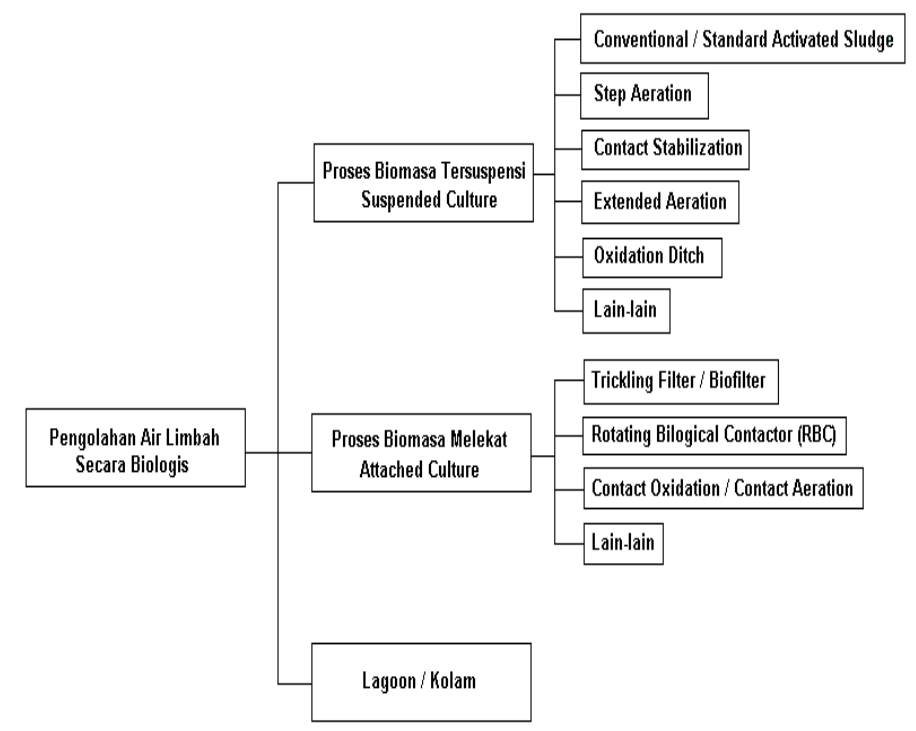

Fig.1. Framework 


\subsection{The Blue Economy principle can be applied to fishing pond water circulation treatment technology}

Table 1. Operational Characteristics of Wastewater Treatment Processes With Biological

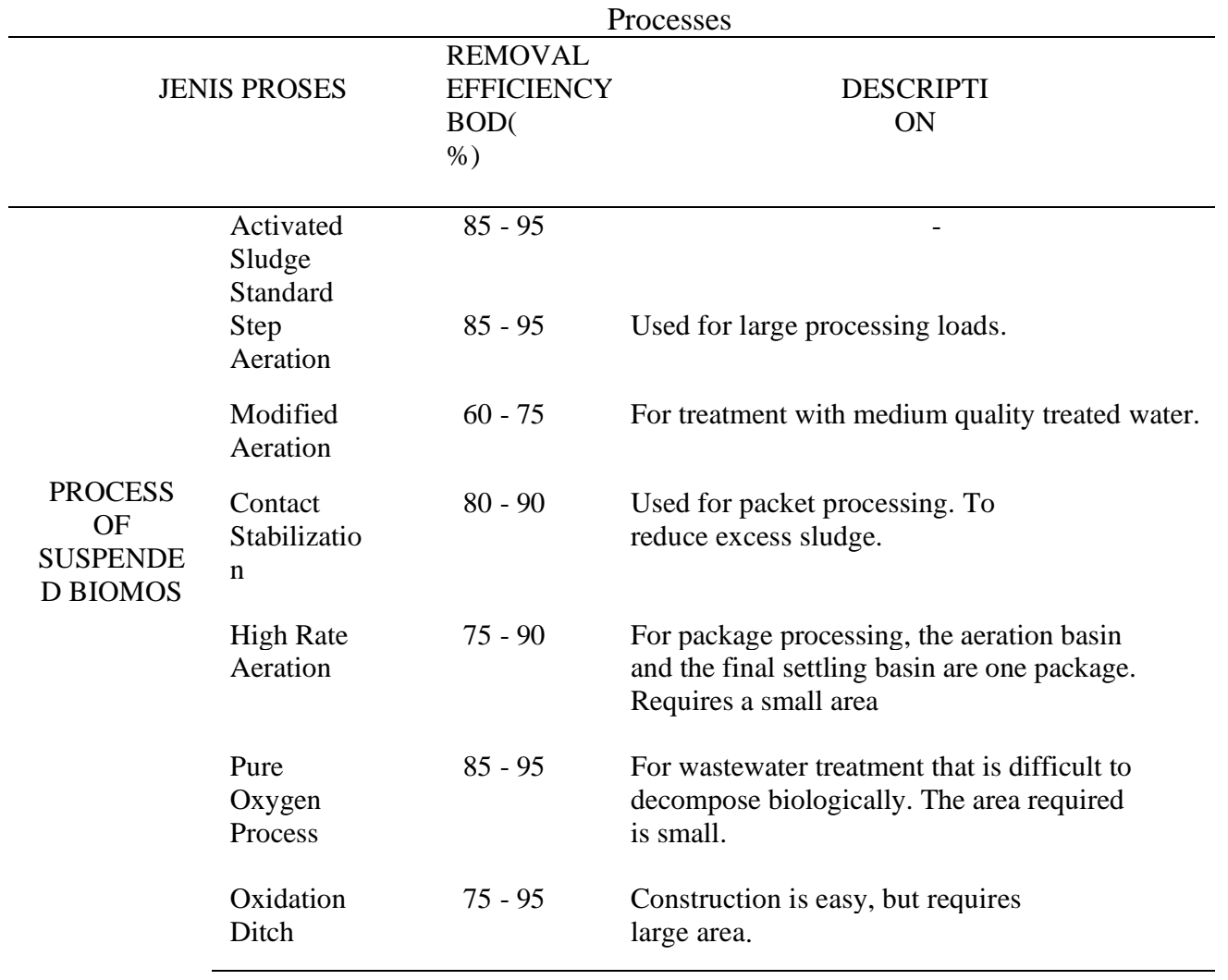

Liquid waste that has been filtered is filtered for a second time with a fine screenwall separating solids ranging in size from 1 to $3 \mathrm{~mm}$. A pump with a capacity of $28 \mathrm{~m} /$ hour to 45 $\mathrm{m}^{3} /$ hour is used to pump liquid waste from the pumping pit through the fine screen wall. , The number of solid particles filtered averages $3.91 / \mathrm{m}^{3}$ of liquid waste. The maximum Total Suspended Solid TSS content in the liquid waste that comes out of the unit fine screen is 3.2 $\mathrm{g} / \mathrm{l}$. The liquid waste that is filtered from the fine screen is then collected in mixing tank. The mixer functions to homogenize liquid waste and is controlled by a timer of 4 to 5 minutes. Without a mixer, sludge would settle at the bottom of the tank. With a mixer the sludge is mixed and only a little settles. The average $\mathrm{pH}$ value of the liquid waste is 6.8 . The liquid waste from the mixing tank is then pumped to a pre-sedimentation tank. Here the sludge particles are deposited. The waste liquid will flow through the gutter into the pumping pit and on to to a fixed bed digester. The $\mathrm{pH}$ value of the wastewater in the pre-sidementation basin is about 7.0. The TSS is an average of $0.54 \mathrm{~g} / \mathrm{l}$, with a minimum value of $0.68 \mathrm{~g} / \mathrm{l}$ and a maximum value of $0.4 \mathrm{~g} / \mathrm{l}$. Sedimentation tank efficiency reaches 72 to $98 \%$. 


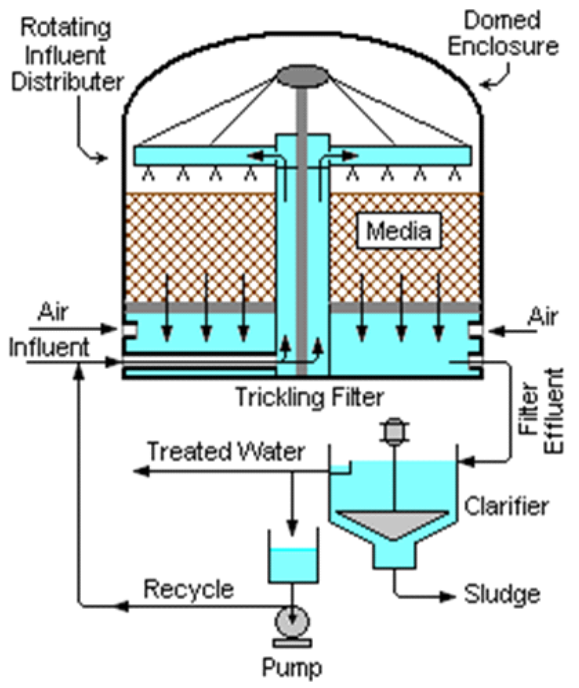

Fig.1. Liquid Waste Filter

\subsection{Metabolic processes in microorganisms}

Equations and formulas.

$$
\text { Oxidation }
$$

$$
\mathrm{CO}_{2}+\mathrm{NH}_{3}+
$$

Last Product + energy

$$
\begin{array}{cc}
\text { COHNS }+\mathrm{O}_{2}+\text { bacteria }+ \text { energy } & \begin{array}{c}
\mathrm{C}_{5} \mathrm{H}_{7} \mathrm{NO}_{2} \\
\text { (new bacteria cell) }
\end{array} \\
\mathrm{C}_{5} \mathrm{H}_{7} \mathrm{NO}_{2}+5 \mathrm{O}_{2} & \begin{array}{c}
\text { Respiration } \\
\text { (organic matter) }
\end{array} \\
& \mathrm{CO}_{2}+\mathrm{NH}_{3}+2 \mathrm{H}_{2} \mathrm{O}+\text { energy }
\end{array}
$$

\subsection{Anaerobic Fermentation Process Of Waste Liquid}

Anaerobic Fixed Bed Reactor (AFBR) is a wastewater treatment which is carried out anaerobically using an embedded microorganism growth system. Microorganisms grow and develop by attaching to a support media. Growing medium for microorganisms can be in the form of pumice, plastic, a glass ring, expanded clay, porcelain and bamboo or other inert material.The supporting media should have the largest porosity and surface area possible. The supporting media used in Senggarang is made of fabricated plastic Liquid waste is pumped into the AFBR through the bottom rector with pipes that are evenly distributed. Waste flows upwards through the appropriate microorganism growth mediumstages of the process When contact occurs between the organic matter and the microorganisms the anaerobic degradation process takes place, Organic load is defined as the amount of organic compounds in wastewater that are removed or degraded in the biofilter per unit volume per day. Very high organic load can affect the growth of microorganisms, and at certain concentrations can cause 
the death of microorganisms, and The hydraulic load is expressed as the volume of waste water that can be treated per unit time per unit surface area of the media. High hydraulic load can cause peeling of the biofilm layer adhering to the media, resulting in lower processing efficiency, Each type of bacteria requires a certain $\mathrm{pH}$ to grow properly. In general, all bacteria have growth conditions between $4-9.5$ with an optimum $\mathrm{pH}$ of 6.5 - 7.5. Overall Reynolds (1985) stated that microorganisms need a $\mathrm{pH}$ of 6.5-9. Bacteria will grow well in slightly alkaline conditions, which ranges from 7-8.

\subsection{Analysis}

The combination of the "Anaerobic-Aerobic" process, the efficiency of removing phosphorus compounds is greater when compared to the anaerobic process, so that inorganic phosphorus compounds present in the cells of microorganisms will come out as a result of the hydrolysis of phosphorus compounds. While the energy produced is used to absorb BOD (organic compounds) in wastewater. During aerobic conditions, dissolved phosphorus compounds will be absorbed by bacteria/microorganisms and will be synthesized into polyphosphates using the energy generated by the oxidation process of organic compounds. (BOD). Thus the combination of anaerobic-aerobic processes can remove both BOD and phosphorus properly. This process can be used for wastewater treatment with a large organic load.

\section{Conclusion}

Monitoring is an activity carried out to monitor the WWTP process which is carried out continuously, and is carried out periodically within a certain period per unit of time such as weekly, monthly and yearly. This really depends on how much influence the monitored aspects have on the sustainability of the WWTP process. Aspects that need to be monitored from the WWTP anaerobic aerobic biofilter system include monitoring the system, condition and function of the WWTP equipment which is a single unit that influences each other. Monitoring is meant to carry out field measurements (in situ) every day on the quality of wastewater which aims to monitor the performance of the WWTP system in order to facilitate early warning in improving the system. The parameters monitored are usually $\mathrm{pH}$, temperature, Ammonia, Dissolved Oxygen (DO), KMnO4, TSS, and wastewater discharge with daily frequency. Monitoring locations at the outlet, inlet and in the aeration tank. In general, this routine monitoring can keep the system running optimally

\section{References}

[1] D. Rosa, F. Figueiredo, É. Castanheira, M. Feliciano, F. Maia, J. Santos, A. P. Silva, Trindade,H., and F. Freire, "Life-Cycle greenhouse gas assessment of Portuguese chestnut",

Conference on Energy for Sustainability 2015-Sustainable Cities: Designing for People and the Planet, pp. 1-6, 2015.

[2] Y. Sun, Z. Chen, G. Wu, Q. Wu, F. Zhang, and Z. Niu, "Characteristics of water quality of municipal wastewater treatment plants in China: Implications for resources utilization andmanagement", Journal of Cleaner Production, vol. 131, pp. 1-9, 2016. 
[3] G. F. Fernandes, and R. A. Oliveira, "Desempenho e processo anaeróbio em dois estágios (Reator compartimentado seguido de reator UASB) para tratamento de águas residuárias desuinicultura", Engenharia Agrícola, vol. 26, pp. 243-256, 2006.

[4] S. Lansing, R. B. Botero, and J. F. Martin, "Waste treatment and biogas quality in smallscaleagricultural digesters”, Bioresource Technology, vol. 99, pp. 5881-5890, 2008.

[5] G. E. Vieira, and G. P. Alexandre, "Tratamento, caracterização e obtenção de bio-óleo combustível a partir da pirólise termocatalítica de lodo de esgoto doméstico", Revista Liberato, vol. 14, pp. 01-104, 2014.

[6] M. D. Szarblewski, R. D. Schneider, and E. L. Machado, "Métodos para a remoção de sulfetode hidrogênio de efluentes”, Revista Jovens pesquisadores, pp. 62-74, 2012.

[7] Y. Chen, J. He, Y. Mu, Y. C. Huo, Z. Zhang, and T. A. Kotsopoulos, "Mathematical modeling of upflow anaerobic sludge blanket (UASB) reactors: Simultaneous accounting for

hydrodynamics and bio-dynamics", Chemical Engineering Science, vol. 137, pp. 677 684,2015 